\title{
Mesenchymal stem cells accelerate liver regeneration in acute liver failure animal model
}

\author{
Agung Putra ${ }^{1,2,3, *{ }^{(}, \text {, Arini Dewi Antari }}{ }^{3}$, Azizah Retno Kustiyah4 ${ }^{4}$, Yulice Soraya Nur Intan ${ }^{5}$, Nur Anna C. \\ Sadyah $^{6}$, Nugraha Wirawan ${ }^{7}$, Samara Astarina ${ }^{7}$, Nasrul Zubir ${ }^{8}$, Delfitri Munir ${ }^{9,10}$
}

${ }^{1}$ Stem Cell And Cancer Research (SCCR), Medical Faculty, Sultan Agung Islamic University (UNISSULA), Semarang, Central Java, Indonesia

\section{Correspondence}

Agung Putra, Stem Cell And Cancer Research (SCCR), Medical Faculty, Sultan Agung Islamic University (UNISSULA), Semarang, Central Java, Indonesia

Email: dr.agungptr@gmail.com

History

- Received: 03 September 2018

- Accepted: 31 October 2018

- Published: 14 November 2018

DOI :

https://doi.org/10.15419/bmrat.v5i11.498

\section{Check for updates}

\section{Copyright}

(c) Biomedpress. This is an openaccess article distributed under the terms of the Creative Commons Attribution 4.0 International license.

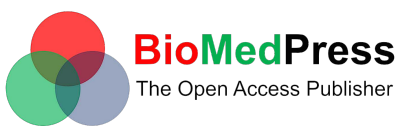

\begin{abstract}
Introduction: The massive hepatic necrosis of acute liver failure (ALF) results in a sudden loss of hepatic cells. Although most hepatocyte cells of ALF are completely lost, stem cell-derived circulating cells and endogenous progenitor cells rapidly regenerate them. Mesenchymal stem cells (MSCs) have a critical role in the regeneration of liver injury through regulating platelet-derived growth factor (PDGF) and vascular endothelial growth factor (VEGF) levels. However, their fluctuating levels in the healing process and correlation to the decrease of liver function markers remain unclear. The aim of this study was to analyze the effects of MSCs in accelerating liver regeneration of ALF by measuring VEGF and PDGF levels on day 2 and 7, as well as SGPT and SGOT levels, and assessing histopathology appearance. Methods: Using an ALF rat model, 12 animals were randomly assigned into two groups: umbilical cord (UC)-MSC injection (T1) and vehicle control (Veh). ELISA assay was employed to measure PDGF and VEGF levels, an automatic analyzer was used to assess serum glutamic pyruvic transaminase (SGPT) and serum glutamic oxaloacetic transaminase (SGOT), and hematoxylin and eosin (H\&E) staining was used to evaluate morphological appearance. Results: The study showed an significant $(P<0.001)$ increase of PDGF and VEGF levels on the $2^{\text {nd }}$ day, followed by a decrease on the $7^{\text {th }}$ day, along with a decrease of SGPT and SGOT levels as well as the normality of histology appearance. Conclusion: In conclusion, administration of MSCs may accelerate liver regeneration of ALF through PDGF and VEGF regulation.
\end{abstract}

Key words: ALF, MSCs, PDGF, SGOT, SGPT, VEGF

\section{INTRODUCTION}

Acute liver failure (ALF) is characterized by extensive hepatic necrosis of multiple lobes or acini, and diffuse intra-hepatic infiltration of inflammatory cells without pre-existing liver disease ${ }^{1}$. The massive inflammation and hepatocyte necrosis of ALF may lead to rapid hepatocellular dysfunction and multiple organ failure which increase mortality rate ${ }^{2}$. Even when the majority of hepatocytes are diminished in ALF, there is still the ability to restore them since hepatocytes are one of the highly regenerative cells. Specifically, the regeneration process is induced by the activation of liver progenitor cells (LPCs) derived from endogenous progenitors (local cells) and or bone marrowderived circulating cells, particularly mesenchymal stem cells (MSCs) ${ }^{3}$. Studies have demonstrated that MSCs have high differentiation potential to specific cells, including primary hepatocytes ${ }^{4}$. These facts suggest that MSCs could accelerate the regeneration process of ALF.

MSCs are defined as a plastic-adherent stromal cells with multipotent differentiation capacity and which express various surface markers, including CD73,
CD90, CD105, CD44 and CD29, while lacking the expression of CD45, CD34, CD14 or CD11b, CD79a or CD19, and Human Leucocyte Antigen (HLA) class II. MSCs are able to differentiate into chondrocytes, osteocytes and adipocytes ${ }^{5}$, including hepatocytes under standard in vitro differentiating conditions ${ }^{6}$. On the other hand, MSCs also have immunosuppression capability by suppressing the release of pro-inflammatory molecules which then trigger regeneration via increasing platelet-derived growth factor (PDGF) and vascular endothelial growth factor (VEGF) levels ${ }^{7}$. The subsequent improved liver function is marked by normal liver enzymes, serum glutamic pyruvic transaminase (SGPT) and serum glutamic oxaloacetic transaminase (SGOT), and histopathological appearance ${ }^{8}$.

Previous studies have reported that VEGF has an important role in enhancing regeneration ${ }^{9}$. Moreover, it directs MSC motility to sites of injury via binding co-receptor CD44 to VEGFR-2 in damaged tissues ${ }^{10}$. Meanwhile, PDGF also plays a role in the initial inflammatory phase as a chemokine molecule to attract inflammatory cells, including MSCs. Un- 
${ }^{2}$ Department of Postgraduate Biomedical Science, Medical Faculty, Sultan Agung Islamic University (UNISSULA),

Semarang, Central Java, Indonesia

${ }^{3}$ Department of Pathological Anatomy, Medical Faculty, Sultan Agung Islamic University (UNISSULA), Semarang, Central Java, Indonesia

${ }^{4}$ Department of Pediatric, Medical Faculty, Sultan Agung Islamic University (UNISSULA),

Semarang, Central Java, Indonesia

${ }^{5}$ Department of Surgical, Medical Faculty, Sultan Agung Islamic University (UNISSULA),

Semarang, Central Java, Indonesia

${ }^{6}$ Department of Internal Medicine, Medical Faculty, Sultan Agung Islamic University (UNISSULA),

Semarang, Central Java, Indonesia

${ }^{7}$ Bachelor of Medical Science Program, Medical Faculty, Sultan Agung Islamic University (UNISSULA), Semarang, Central Java, Indonesia

${ }^{8}$ Department of

Gastroenterohepatology, Medical Faculty, Andalas University, Padang, West Sumatera, Indonesia

${ }^{9}$ Faculty of Medicine, Sumatera Utara University, Medan, North Sumatera, Indonesia

${ }^{10}$ Pusat Unggulan Inovasi (PUI) Stem Cell, Sumatera Utara University (USU), Medan, North Sumatera, Indonesia der controlled inflammation, VEGF and PDGF trigger the proliferation phase ${ }^{11,12}$.

Several studies have demonstrated that the MSCs may migrate to the injured sites, including in ALF, due to their MSC-like leukocyte properties. To reach the target areas, MSCs respond to liver injuryreleased chemoattractant molecules, such as stromal cell-derived factor 1 (SDF-1), basic fibroblast growth factor (bFGF), and VEGF. In injury areas, MSCs may suppress the inflammation process by releasing several anti-inflammatory cytokines, such as TSG-6, PGE2, IL-1ra, IDO, NO, IL-10 and TGF- $\beta$, that alter inflammation to proliferation phase ${ }^{13}$. This process may accelerate the regeneration of injured cells in ALF, marked by increasing PDGF and VEGF levels which correlate to normality of liver function. However, the excess of PDGF and VEGF levels can also exert deleterious effects and are associated with increased fibrosis ${ }^{14}$. Therefore, controlling the fluctuation of PDGF and VEGF levels by MSCs, particularly in inflammation and proliferation phase, is needed. The aim of this study was to analyze the role of PDGF and VEGF released by MSCs (on days 2 and 7) in ALF that are associated with the improvement of SGOT and SGPT levels, as well as histological appearance.

\section{METHODS}

\section{Isolation of MSCs}

Umbilical cord (UC) derived MSCs (UC-MSCs) were obtained from pregnant single Sprague-Dawley (SD) rats under deep anesthesia and transplanted into an ALF rat model. Briefly, the umbilical cord was cut into pieces after the blood vessels were removed and then transferred to a T25 culture flask containing complete Dulbecco's Modified Eagle's medium (DMEM) (Sigma-Aldrich, Louis St, MO) mixed with $10 \%$ Fetal Bovine Serum (FBS) (Gibco ${ }^{\mathrm{TM}}$ Invitrogen, NY, USA), and $100 \mathrm{IU} / \mathrm{mL}$ penicillin/streptomycin (Sigma-Aldrich). These cells were incubated in a 5\% $\mathrm{CO}_{2}, 37^{\circ} \mathrm{C}$ incubator and the medium was changed every 3 days. After cells reached $80 \%$ confluency, the MSC-like cells were passaged with trypsin. Cells from the $4^{\text {th }}$ passage were used for experiments. This study was approved by the Institutional Review Board of the Ethics Committee of the Medical Department, Sultan Agung Islamic University, in Semarang, Indonesia.

\section{Acute liver failure (ALF) animal model}

Twelve male SD rats weighing $200 \mathrm{~g}$ (5-weeks of age) were placed in cages at $24^{\circ} \mathrm{C}$ with $12 \mathrm{~h}$ light dark cycle, and fed with water and food. All of the rats were induced by intraperitoneal injection of $0.1 \mathrm{~mL} / \mathrm{kg}$ carbon tetrachloride $\left(\mathrm{CCl}_{4}\right)$ (Sigma-Aldrich) dissolved in olive oil (1:1) 2 times per week for 2 weeks to induce ALF in the animals.

\section{Flow cytometric immunophenotyping of UC-MSCs}

The immunophenotypes of UC-MSCs were analyzed at fourth passage. UC-MSCs were stained with antibodies conjugated: fluorescein isothiocyanate (FITC)-conjugated CD90, Allophycocyanin (APC)conjugated CD73, Peridinin Chlorophyll Protein Complex (PerCP)-conjugated CD105 and phycoerythrin (PE)-conjugated Lin monoclonal antibodies for $30 \mathrm{~min}$ at $4^{\circ} \mathrm{C}$ in the dark. The fluorescence intensity of the cells was evaluated through flow cytometry (BD Bioscience, Franklin Lakes, NJ, USA).

\section{In Vitro Differentiation}

UC-MSC differentiation potential was determined in order to characterize the isolated cells. These cells were cultured in DMEM medium supplemented with $10 \% \mathrm{FBS}, 10 \mathrm{mmol} / \mathrm{L} \beta$ glycerophospate, $10^{-7}$ $\mathrm{mol} / \mathrm{L} / 0.1 \mu \mathrm{M}$ dexamethasone, $50 \mu \mathrm{mol} / \mathrm{L}$ ascorbate2-phosphate (all from Sigma-Aldrich, Louis St, MO), at $37^{\circ} \mathrm{C}$ and $5 \% \mathrm{CO}_{2}$. The fixed cells were stained with $0.2 \%$ Alizarin Red solution (Sigma-Aldrich) to represent calcium deposition (cells used were from the 4 th passage).

\section{Administration of MSCs}

We isolated MSCs from single rat umbilical cord and transplanted the UC-MSCs into other rats (allogenic transplantation). Experimental rats were randomly assigned into the UC-MSC injection group ( $\mathrm{T} 1, \mathrm{n}=6)$, which received $1 \times 10^{6}$ UC-MSCs dissolved in $1 \mathrm{~mL}$ $\mathrm{NaCl}$, or the vehicle control group (Veh, $\mathrm{n}=6$ ), which received only $\mathrm{NaCl}$; administration was done via lateral tail vein injection.

\section{Histological Analysis}

All experimental rats were sacrificed by cervical dislocation on the $7^{\text {th }}$ day after MSC injection. The liver tissue of each animal was fixed in 10\% formaldehyde, embedded with paraffin, and sectioned. The histological appearance was observed after hematoxylin \& eosin (H\&E) staining at high magnification.

\section{Enzyme-linked immunosorbent assay (ELISA)}

The blood of rats was harvested via periorbital venous plexus bleeding under general anesthesia on days 0 (pre-treatment), 2 and 7, and the serum was collected by centrifugation at $4^{\circ} \mathrm{C}$. We measured PDGF and 
VEGF concentrations by enzyme-linked immunosorbent assay (ELISA) kits, based on the manufacturer's instructions (Fine Test, Wuhan, China) and according to a standard curve constructed for each assay. The colorimetric absorbance was recorded at a wavelength of $450 \mathrm{~nm}$.

\section{Liver function enzyme assays}

SGOT and SGPT were measured to determine liver functions at days 0 (pre-treatment) and 7. Blood samples were collected from periorbital veins under anesthesia with ketamine + xylazine $(100 \mathrm{mg} / \mathrm{kg}+5$ $\mathrm{mg} / \mathrm{kg}$ i.m.) (Alfasan, Netherlands). The serum was collected by centrifugation at $4^{\circ} \mathrm{C}$. SGOT and SGPT serum levels were measured using an automatic analyzer (BT 3000 PLUS, Italy).

\section{RESULTS}

\section{Characteristics of UC-MSCs}

After 4 passages, the expression of specific markers of UC-MSCs were evaluated using flow cytometric analysis (Figure 1). The results showed that the isolated cells expressed a MSC-specific marker profile. Indeed, the showed positive expression of CD105 (96.7\%), CD73 (99.2\%), and CD90 (96.7\%), but were negative for Lin $(0.03 \%)$. Note that the $\mathrm{Lin}^{-}$ cell subset serves as a hematopoetic lineage negative marker, according to the International Society of Cellular Therapy (ISCT) Figure 1.

\section{Isolation and osteogenic differentiation of UC-MSCs}

UC-MSC isolation was performed based on the plastic adherent capacity under standard culture conditions $\left(37^{\circ} \mathrm{C}, 5 \% \mathrm{CO}_{2}\right)$. The isolated cells showed peculiar fibroblast-like (spindle shape) morphology (magnification x10, scale bar $200 \mu \mathrm{m}$ ) (Figure 2A). To determine and verify the multi-lineage differentiation of UC-MSCs, we assessed osteogenic differentiation after 4 passages. The differentiation assay indicated that the multipotency of cultured UC-MSCs was well-maintained which was identified as calcium deposits (red color) by Alizarin red dye (Figure 2B) (magnification $\mathrm{x} 40$, scale bar $50 \mu \mathrm{m}$ ).

\section{Histological analysis}

To confirm the effects of the treatment groups and that they were conducted in an ALF animal model, the liver tissues of pre-treated animals were stained by H\&E (Figure 3A). The result showed that the hepatocytes of pre-treatment group are ballooned, with rounded plasma membrane contours. These indicated that all animal model groups were in ALF condition. The effects of UC-MSCs on liver tissue of animals in the ALF model were evaluated by H\&E staining of liver tissue slides. The results showed that there were different morphologies of the hepatocytes in the vehicle treatment group versus the UC-MSC treatment group. The histological features of liver tissues treated with UC-MSCs (Figure 3C) showed normal arrangement of hepatocytes, narrow sinusoid and small hepatic arteries, compared to vehicle group (on the $7^{\text {th }}$ day) (magnification x10). In the vehicle group, there was sinusoidal dilatation and irregular shape of small twigs with hyperchromatic nuclei.

\section{VEGF and PDGF levels}

We performed the level of VEGF and PDGF (five replicates per sample). The analysis of PDGF concentration showed that there was significant increase $(\mathrm{P}<0.05)$ in treatment group at the $2^{\text {nd }}$ day $(343.67 \pm 5.21 \mathrm{pg} / \mathrm{mL})$, compared to the vehicle group $(290.42 \pm 7.61 \mathrm{pg} / \mathrm{mL})$. However, there was significant decrease $(\mathrm{P}<0.05)$ in treatment group at $7^{t h}$ day $(263.79 \pm 3.99 \mathrm{pg} / \mathrm{mL})$, compared to the vehicle control $(315.80 \pm 5.82 \mathrm{pg} / \mathrm{mL})$. Furthermore, VEGF concentration also showed significant increase $(\mathrm{P}<0.05)$ in treatment group at $2^{\text {nd }}(110.11 \pm 2.41 \mathrm{pg} / \mathrm{mL})$ and $7^{t h}$ day $(110.31 \pm 6.01 \mathrm{pg} / \mathrm{mL})$. Thus, the optimal concentration was found on the $2^{\text {nd }}$ day Figure 4.

\section{SGPT and SGOT levels}

SGPT and SGOT levels were measured to determine the liver functions. The results of the pre-treatment group (day 0) showed high levels of SGPT (>200 U/L) and SGOT $(>300 \mathrm{U} / \mathrm{L})$, which indicate that all treated animals were undergoing ALF. The result showed that there was significant decrease $(\mathrm{P}<0.05)$ in SGPT $(52.40 \pm 4.72 \mathrm{U} / \mathrm{L})$ and SGOT $(105.80 \pm 10.32 \mathrm{U} / \mathrm{L})$ levels on day $7^{\text {th }}$ in the treatment group, as compared to vehicle group (SGPT $=128.60 \pm 15.93 \mathrm{U} / \mathrm{L}$; $\mathrm{SGOT}=146.80 \pm 10.49 \mathrm{U} / \mathrm{L}$ ) Figure 5.

\section{DISCUSSION}

In recent years, UC-MSCs have been used as a new therapeutic paradigm for a number of diseases in regenerative medicine. Several studies have shown that stem cell based therapy may reduce liver inflammation and improve hepatocyte cell regeneration. Thus, use of UC-MSCs could be a promising strategy for liver injury, including ALF. The massive progression of necrosis of liver cells in ALF may result from a sudden loss of hepatic cells which potentially lead to multiple organ failure and death ${ }^{11}$. Therefore, a new treatment approach focusing on liver regeneration would 

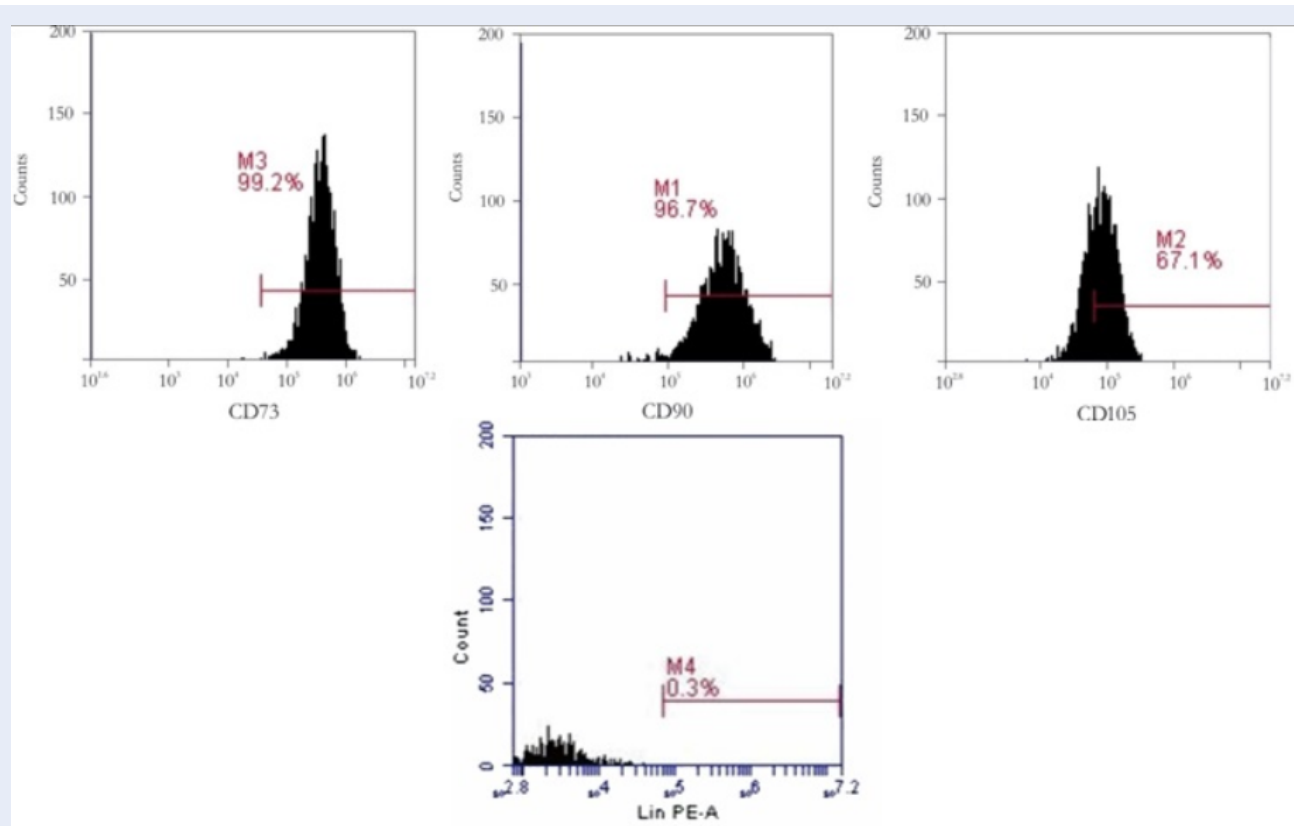

Figure 1: UC-MSC characteristics by flow cytometry. Flow cytometry analysis of UC-MSC related immunophenotypes. Most UC-MSCs expressed positive markers (CD105, CD73, and CD90) but did not express the negative marker Lin $\left(\operatorname{Lin}^{-}\right)$.
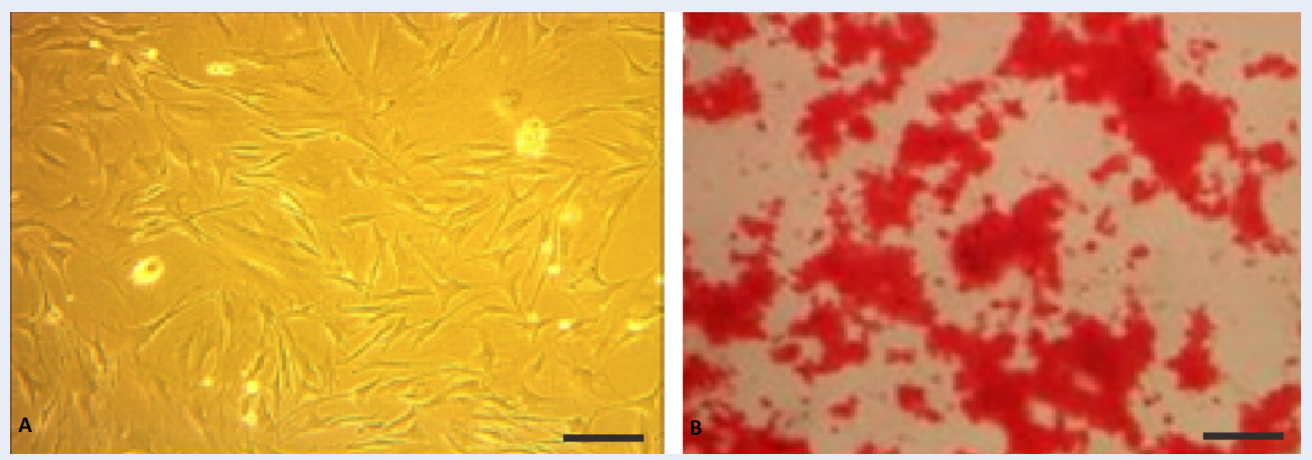

Figure 2: Isolation and differentiation of UC-MSCs. (A) UC-MSC candidates from the in vitro culture showed fibroblast-like cell characteristics (magnification10x, scale bar $200 \mu \mathrm{m}$ ); (B) Differentiation assays revealed that UC-MSCs could differentiate into osteocytes- via staining by Alizarin red which enabled osteocytes to appear red among the MSC population (magnification 40x, scale bar $50 \mu \mathrm{m}$ ).

provide great clinical value. To analyze the effects of MSCs on accelerating liver regeneration of ALF, we used carbon tetrachloride $\left(\mathrm{CCl}_{4}\right)$-injected SpragueDawley rats as an established ALF animal model, according to previous protocols ${ }^{15}$. In this study, we injected UC-MSCs into SD rats via i.v. route and then analysing VEGF and PDGF levels on day 2 and 7. We also measured SGOT and SGPT levels, as well as histopathological appearance on day 7.

We found that the PDGF and VEGF levels were significantly increased on the $2^{\text {nd }}$ day $(\mathrm{p}<0.05)$. It was pre- sumed that the inflammation process of ALF had been controlled post UC-MSC administration. Undercontrolled inflammation processes promote the shifting of inflammation to the proliferation phase, as indicated by release of PDGF and VEGF as potent proliferation molecules (Figure 4B). On the contrary, in the control group, the levels of PDGF and VEGF are much lower due to the fact that the inflammation process is still in progress.

In addition, inflammation releases several inflammatory molecules, particularly serine proteases (SPs), 

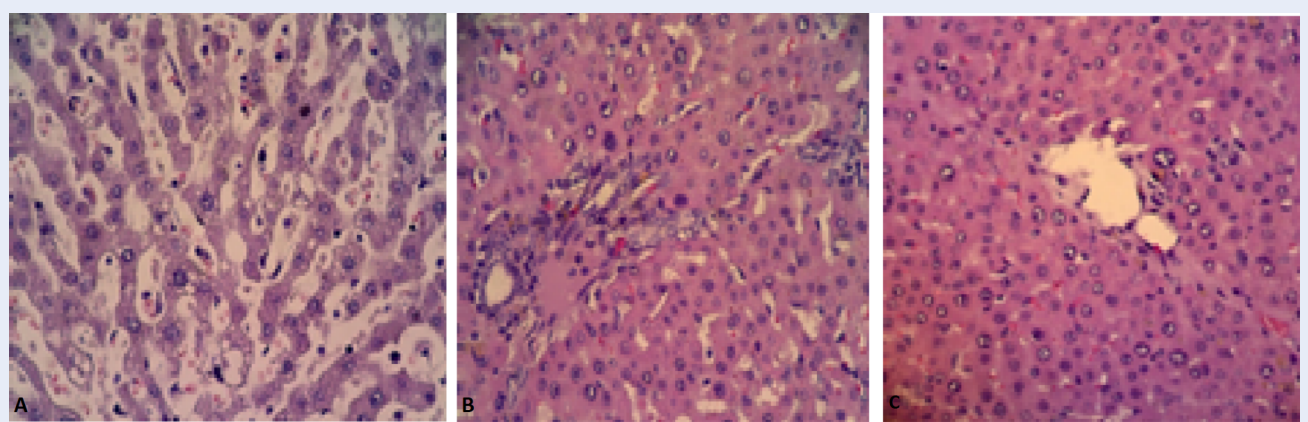

Figure 3: Histopathological appearance. (A) Slide of the pre-treatment group showed damaged hepatocytes cells; (B) The hepatocytes of the vehicle group (on the $7^{\text {th }}$ day) showed an irregular shape of small twigs with hyperchromatic nuclei; (C) The UC-MSC group showed normal arrangement of hepatocytes, narrow sinusoid, and small hepatic arterial structure (on the $7^{\text {th }}$ day; magnification 10x).

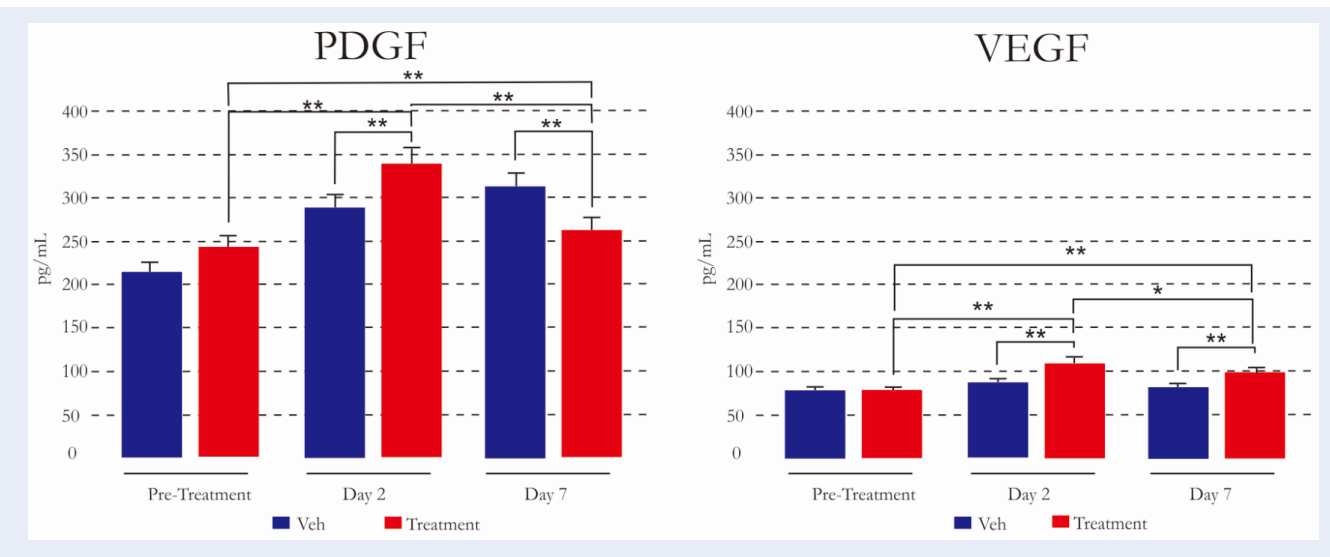

Figure 4: Assessment of VEGF and PDGF levels. (A) ELISA assay showed an increase of PDGF levels at the $2^{\text {nd }}$ day $(343.67 \pm 5.21 \mathrm{pg} / \mathrm{mL})$, and a decrease at the $7^{\text {th }}$ day $(263.79 \pm 3.99 \mathrm{pg} / \mathrm{mL})$. On the other hand, (B) VEGF levels were increased at the $2^{\text {nd }}$ day $(110.11 \pm 2.41 \mathrm{pg} / \mathrm{mL})$ and at 7 th day $(101.306 \pm 2.21 \mathrm{pg} / \mathrm{mL}) .{ }^{*}, \mathrm{P}<0.05$, $^{* *}$, $\mathrm{P}<0.001$.

that trigger the proteolytic microenvironment state, leading to degradation of PDGF and VEGF ${ }^{12,16}$. Specifically, in addition to proliferation, the significant increase of VEGF level at the $2^{\text {nd }}$ day post MSC administration indicated that the MSCs are also actively releasing several chemokine molecule for homing of other circulating MSCs to sites of liver injury ${ }^{17}$. This study is in accordance with a previous study which showed the MSC homing process to injured area due to stimulation of specific molecules, namely stromal derived factor-1 (SDF-1), integrin $\alpha 4$, integrin $\beta 1$ forming very late antigen 4 (VLA-4), and VEGF $^{14}$ (Figure 7).

On the other side, VEGF is well-known to play a role as a potent angiogenic factor in hepatocyte regeneration. It has been reported that VEGF expression is related to liver regeneration after chronic liver injury or partial hepatectomy in rats. Moreover, VEGF also produces a significant suppression of hepatocyte apoptosis, indicating that VEGF may reduce mortality rates in $\mathrm{ALF}^{18}$. Moreover, PDGF may play role in proliferation based on the high expression at day 2 . Previous studies have demonstrated that PDGF has an essential role in liver fibrogenesis, potentially acting as a potent mitogen for hepatic stellate cell (HSC) growth ${ }^{19}$. This cytokine also plays a role in the initiation phase of hepatocyte regeneration and prevention of hepatocyte apoptosis through Akt or ERK1/2 pathway activation ${ }^{20}$.

In sites of injury, MSCs suppress the inflammation process and then promote the proliferation phase. MSCs actively induce the activation of endogenous stem cell to accelerate liver regeneration in ALF; this is known as a paracrine mechanism. This mechanism simultaneously improve the regeneration of hepatocyte cells to an optimal state, then gradually decreases 

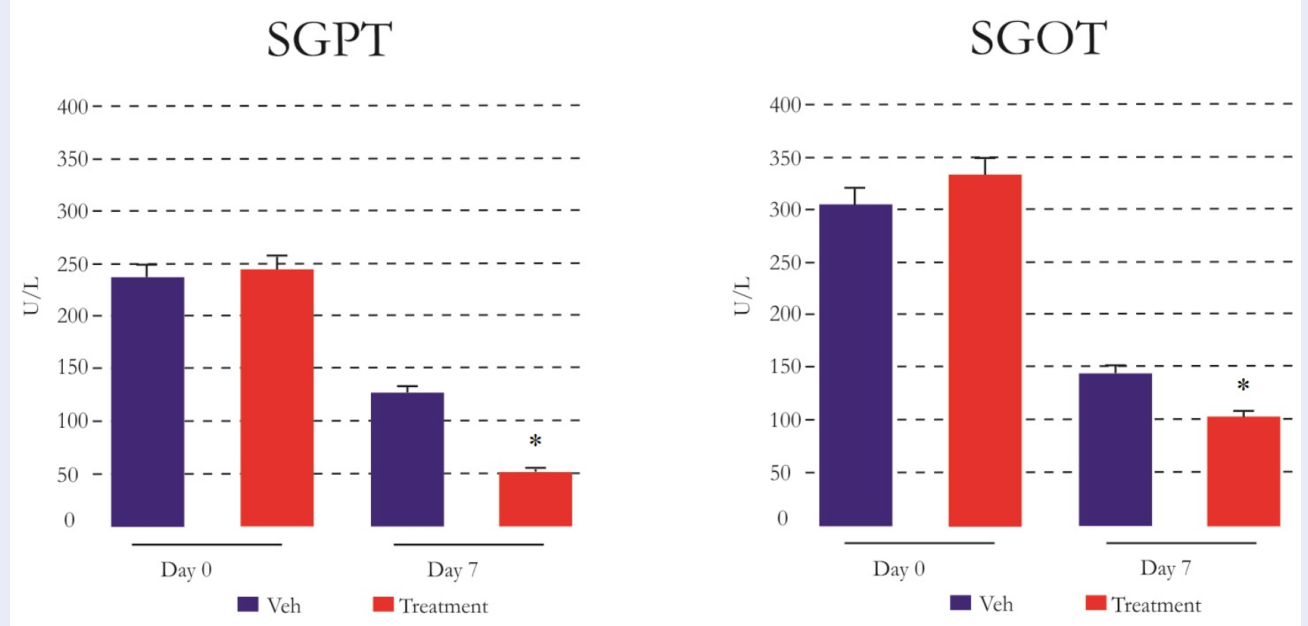

Figure 5: SGOT and SGPT levels. There were high levels of SGPT ( $>200 \mathrm{U} / \mathrm{L})$ and SGOT ( $>300 \mathrm{U} / \mathrm{L}$ ) in the pretreatment group (day 0 ) which were significantly decreased $(\mathrm{P}<0.05)$ in the treatment group at day $7^{\text {th }}$ (SGPT (52.40 $\pm 4.72 \mathrm{U} / \mathrm{L})$ and SGOT (105.80 $\pm 10.32 \mathrm{U} / \mathrm{L}))$. U/L: units/Liter
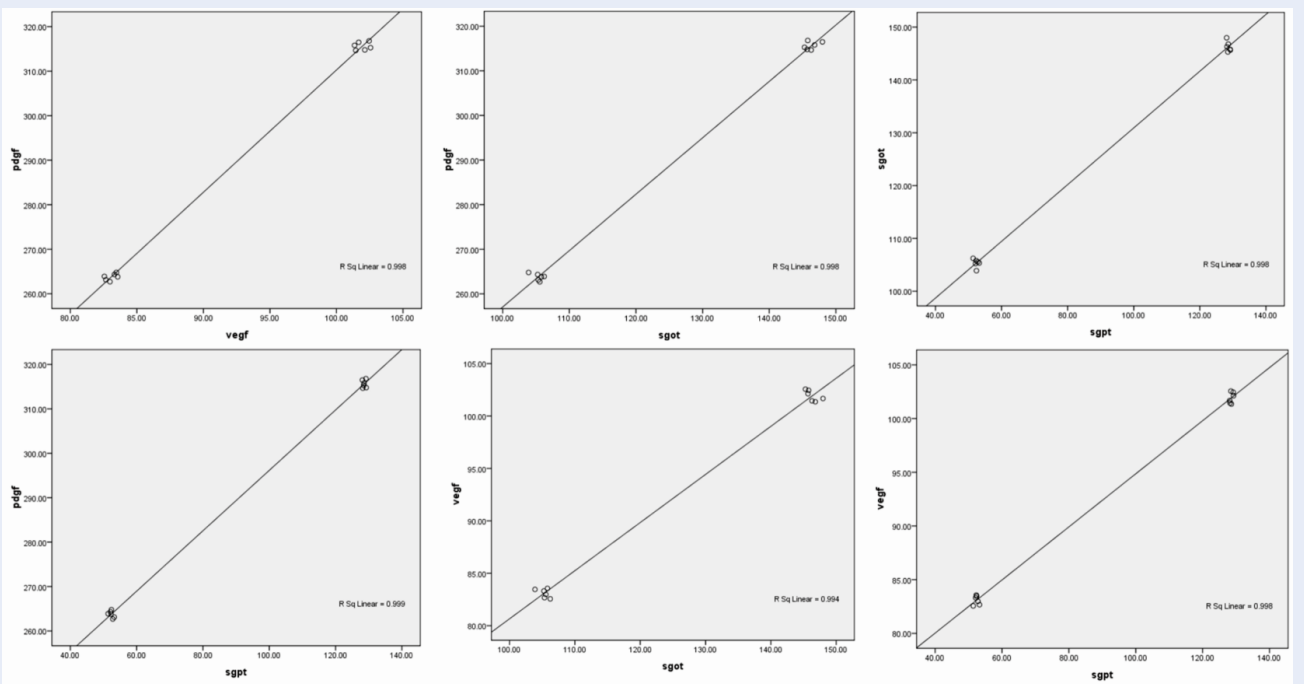

Figure 6: Correlation chart between PDGF, VEGF, SGOT and SGPT. The results of PDGF, VEGF, SGPT, and SGOT on the $7^{t h}$ day showed that there was a strong (0.99) coefficient between PDGF and VEGF with levels of SGPT and SGOT. This suggests that an increase in PDGF and VEGF in the administration of MSCs provides results that are in line with the regeneration of liver function.

the regeneration ${ }^{21}$. This is in line with our study results which show that PDGF and VEGF levels significantly decreased at day 7 , in accordance with improvement of SGOT and SGPT levels (clinical markers) (Figure 6). Our study shows that there were also significant decreases in SGOT and SGPT levels at day $7(\mathrm{p}<0.05)$ (Figure 5). This suggest that the regeneration process of ALF had been completed in the MSC treatment group, as indicated by the normal liver function. The decrease of PDGF and VEGF plays an important role in controlling the normal structure of liver cellular of ALF due to upregulation of their levels, particularly at a proliferation phase correlated with fibrotic disease ${ }^{22}$. Specifically, PDGF is the most potent mitogen for activating hepatic stellate cells (HSCs) to trigger extracellular matrix synthesis. This fact is supported by a previous study that demonstrated that PDGF-activated HSCs play a vital role in 


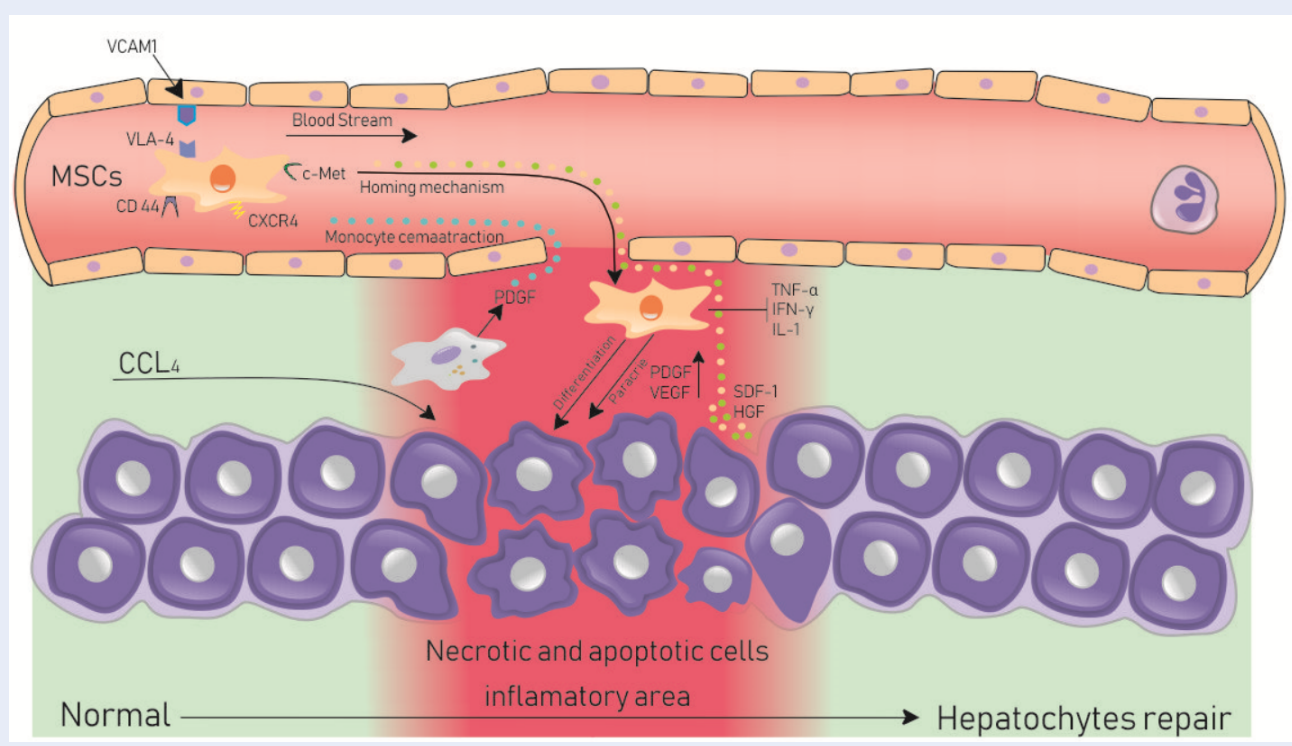

Figure 7: MSC homing mechanism. The interactions of receptor (CXCR4 and cMet)-chemokine (SDF-1 and HGF) andreceptor (VLA-4)-ligand (VCAM-1) lead to cell-cell contact between endothelial cells and MSCs. Thus promoting the migration (homing) of MSCs to sites of liver injury. The activated MSCs release anti-inflammatory molecules, such as PGE2,TSG-6 and IL-1Ra, to control for the inflammation process. These trigger the shift of inflammatory to proliferating phase which is characterized by there lease of PDGF and VEGF. The release of VEGF and PDGF levels at proliferation phase is correlated with the formation of hepatocytes. Then, gradual decrease along with a completed regeneration is characterized by the normal arrangement of hepatocyte cells.

progression of liver fibrosis ${ }^{23}$.

In this study, we also found that the normal appearance of hepatocyte cells in rats from the MSC treatment group at day 7 , which indicates a normal arrangement of hepatocytes, such as those from the narrow sinusoid and/or small hepatic arteries (Figure 3). On the contrary, we found mostly sinusoidal dilatation in the vehicle treatment (control) group, as well as an irregular shape of small twigs with hyperchromatic nuclei. These suggest that liver tissues of rats in the control group were still in the proliferation process. This observation shows that MSC treatment group was faster than vehicle control group in accelerating liver regeneration of ALF through PDGF and VEGF regulation. These regulations initially increase the inflammatory phase, reach an optimum point in the proliferation phase, and then gradually decreases to normal levels in the remodeling phase ${ }^{24}$.

The limitation of this study is that we did not analyze the in-situ existence (of liver tissue) of MSCs $24 \mathrm{~h}$ after administration. Hence, we do not have a clear observation of the MSC homing mechanisms. We also did not analyze other soluble factors that may effect the regeneration process.

\section{CONCLUSIONS}

We conclude that MSCs can accelerate the regeneration process in ALF by regulating the PDGF and VEGF levels. This is in accordance with the improvement of SGPT and SGOT (liver function) as well as normal arrangement of hepatocyte cells. This study provides new insight on the benefits of MSC administration in most injured tissues, particularly in ALF.

\section{COMPETING INTERESTS}

The author(s) declare that they have no competing interests.

\section{AUTHORS' CONTRIBUTIONS}

Agung Putra: A, C, D, E, H

Arini Dewi Antari: F, H

Azizah Retno Kustiyah: C

Yulice Soraya Nur Intan: C

Nur Anna C. Sadyah: I

Nugraha Wirawan: G

Samara Astarina: J

Nasrul Zubir: I, H

Delfitri Munir: B, D

Contribution codes : A : Conception and design; B: Analysis and interpretation of the data ; C: Drafting 
of the article; D: Critical revision of the article for important intellectual content; E: Final approval of the article; F: Provision of study materials or patients; G: Statistical expertise; $\mathbf{H}$ : Obtaining of funding; I: Administrative, technical or logistic support; J: Collection and assembly of data.

\section{ACKNOWLEDGMENTS}

We would like to thanks to Stem Cell and Cancer Research Laboratory, Medical Faculty, Universitas Islam Sultan Agung Semarang for all Facility to finish this research.

\section{ABBREVIATIONS}

ALF: Acute Liver Failure

APC: Allophycocyanin

bFGF: basic fibroblast growth factor

CCl4: Carbon tetrachloride

CO2: Carbon dioxside

DMEM: Dulbecco's modified Eagle medium

ELISA: Enzyme-linked immunosorbent assay

FBS: Fetal Bovine Serum

FITC: Fluorescein Isothiocyanate

HE: Hematoxylin-and-eosin

HSCs: Hepatic stellate cells

IDO: Indoleamine 2,3-dioxygenase

IL-10: Interleukin-10

IL-1ra: Interleukin-1 receptor antagonist

ISCT: International Society of Cellular Therapy.

LPC: Liver progenitor cell

MSCs: Mesenchymal Stem Cells

$\mathrm{NaCl}$ : Natrium Clorida

NO: Nitrit Oxide

PDGF: Platelet Derived Growth Factor

PE: Phycoerythrin

PGE2: Prostaglandin E2

SD: Sprague-Dawley

SDF-1: Stromal Derived Factor-1

SGOT: Serum Glutamic Oxaloacetic Transaminase SGPT: Serum Glutamic Piruvic Transaminase SPs: Serine Proteases

TGF- $\beta$ : Transforming Growth Factor-beta

TSG-6: Tumor necrosis factor-inducible gene 6

UC-MSCs: Umbilical Cord-Mesenchymal Stem Cells VEGF: Vascular Endothelial Growth Factor

VEGFR-2: Vascular Endothelial Growth Factor Reseptor-2

\section{REFERENCES}

1. Lee WM. Acute liver failure. Seminars in Respiratory and Critical Care Medicine. 2012;33:36-45. Available from: DOI: 10.1055/s-0032-1301733.

2. Krysko DV, Denecker G, Festjens N, Gabriels S, Parthoens E, DH屰rde K. Macrophages use different internalization mechanisms to clear apoptotic and necrotic cells. Cell Death and Differentiation. 2006;13:2011-22. Available from: DOI:10.1038/ sj.cdd. 4401900 .
3. Itoh $\mathrm{T}$, Miyajima A. Liver regeneration by stem/progenitor cells. Hepatology (Baltimore, Md). 2014;59:1617-26. Available from: DOI:10.1002/hep.26753.

4. Zhou X, Cui L, Zhou X, Yang Q, Wang L, Guo G. Induction of hepatocyte-like cells from human umbilical cord-derived mesenchymal stem cells by defined microRNAs. Journal of Cellular and Molecular Medicine. 2017;21:881-93. Available from: DOI:10.1111/jcmm.13027.

5. Dominici M, Blanc KL, Mueller I, Slaper-Cortenbach I, Marini F, Krause D. Minimal criteria for defining multipotent mesenchymal stromal cells. The International Society for Cellular Therapy position statement. Cytotherapy. 2006;8:315-7. Available from: Doi:10.1080/14653240600855905.

6. Chivu M, Dima SO, Stancu Cl, Dobrea C, Uscatescu V, Necula LG. In vitro hepatic differentiation of human bone marrow mesenchymal stem cells under differential exposure to liverspecific factors. Translational Research ; the Journal of Laboratory and Clinical Medicine. 2009;154:122-32. Available from: DOI:10.1016/j.trsl.2009.05.007.

7. Kocabayoglu P, Lade A, Lee YA, Dragomir AC, Sun X, Fiel MI. ?-PDGF receptor expressed by hepatic stellate cells regulates fibrosis in murine liver injury, but not carcinogenesis. Journal of Hepatology. 2015;63:141-7. Available from: DOI:10.1016/j jhep.2015.01.036.

8. Zhou R, Li Z, He C, Li R, Xia H, Li C. Human umbilical cord mesenchymal stem cells and derived hepatocyte-like cells exhibit similar therapeutic effects on an acute liver failure mouse model. PLoS One. 2014;9:e104392. Available from: DOI: 10.1371/journal.pone.0104392.

9. Schichor C, Birnbaum T, Etminan N, Schnell O, Grau S, Miebach S. Vascular endothelial growth factor A contributes to gliomainduced migration of human marrow stromal cells (hMSC) Experimental Neurology. 2006;199:301-10. Available from: DOI:10.1016/j.expneurol.2005.11.027.

10. Aldridge V, Garg A, Davies N, Bartlett DC, Youster J, Beard $\mathrm{H}$. Human mesenchymal stem cells are recruited to injured liver in a ?1-integrin and CD44 dependent manner. Hepatology (Baltimore, Md). 2012;56:1063-73. Available from: DOI: 10.1002/hep.25716.

11. Detry O, Vandermeulen M, Delbouille MH, Somja J, Bletard N, Briquet A. Infusion of mesenchymal stromal cells after deceased liver transplantation: A phase I-II, open-label, clinical study. Journal of Hepatology. 2017;67:47-55. Available from: DOI:10.1016/j.jhep.2017.03.001.

12. Nugraha A, Putra A. Tumor necrosis factor-?-activated mesenchymal stem cells accelerate wound healing through vascular endothelial growth factor regulation in rats. Universa Medicina. 2018;37:125-32. Available from: DOI:10.18051/ UnivMed.2018.v37.135-142.

13. Prockop DJ, Oh JY. Mesenchymal stem/stromal cells (MSCs): role as guardians of inflammation. Molecular Therapy. 2012:20:14-20. Available from: DOI:10.1038/mt.2011.211.

14. Bai Q, An J, Wu X, You H, Ma H, Liu T. HBV promotes the proliferation of hepatic stellate cells via the PDGF-B/PDGFR-? signaling pathway in vitro. International Journal of Molecular Medicine. 2012:30:1443-50. Available from: DOI:10.3892/ ijmm.2012.1148.

15. Meier RP, Mahou R, Morel P, Meyer J, Montanari E, Muller $\mathrm{YD}$, et al. Microencapsulated human mesenchymal stem cells decrease liver fibrosis in mice. Journal of Hepatology. 2015;62:634-641.

16. Eming SA, Krieg T, Davidson JM. Inflammation in wound repair: molecular and cellular mechanisms. The Journal of Investigative Dermatology. 2007;127:514-25. Available from: DOI:10.1038/sj.jid.5700701.

17. Becker AD, Riet IV. Homing and migration of mesenchymal stromal cells: how to improve the efficacy of cell therapy? World Journal of Stem Cells. 2016:8:73-87. Available from: DOI:10.4252/wjsc.v8.i3.73. 
18. Tanaka Y, Sohda T, Matsuo K, Anan A, Irie M, Takeyama Y. Vascular endothelial growth factor reduces Fas-mediated acute liver injury in mice. Journal of Gastroenterology and Hepatology. 2008;23:e207-11. Available from: DOI:10.1111/j.14401746.2007.05135.x.

19. Stock $\mathrm{P}$, Monga $\mathrm{D}$, Tan $\mathrm{X}$, Micsenyi A, Loizos N, Monga SP. Platelet-derived growth factor receptor-?: a novel therapeutic target in human hepatocellular cancer. Molecular Cancer Therapeutics. 2007;6:1932-41. Available from: Doi:10.1158/ 1535-7163.mct-06-0720.

20. Matsuo R, Ohkohchi N, Murata S, Ikeda O, Nakano Y, Watanabe M. Platelets strongly induce hepatocyte proliferation with IGF-1 and HGF in vitro. The Journal of Surgical Research 2008;145:279-86. Available from: DOI:10.1016/j.jss.2007.02. 035.

21. Chen L, Xu Y, Zhao J, Zhang Z, Yang R, Xie J. Conditioned Medium from Hypoxic Bone MarrowDerived Mesenchymal Stem Cells Enhances Wound Healing in Mice. PLoS
One. 2014;9:1-12. Available from: DOI:10.1371/journal.pone. 0096161.

22. Choi JW, Kim S, Kim TM, Kim YM, Seo HW, Park TS. Basic fibroblast growth factor activates MEK/ERK cell signaling pathway and stimulates the proliferation of chicken primordia germ cells. PLoS One. 2010;5:e12968. Available from: DOI: 10.1371/journal.pone.0012968.

23. Liu T, Mu H, Shen Z, Song Z, Chen X, Wang Y. Autologous adipose tissue-derived mesenchymal stem cells are involved in rat liver regeneration following repeat partial hepatectomy. Molecular Medicine Reports. 2016;13:2053-9. Available from: DOI:10.3892/mmr.2016.4768.

24. Cheng B, Liu HW, Fu XB, Sun TZ, Sheng ZY. Recombinant human platelet-derived growth factor enhanced dermal wound healing by a pathway involving ERK and c-fos in diabetic rats. Journal of Dermatological Science. 2007;45:193-201. Available from: DOI:10.1016/j.jdermsci.2006.11.014. 